\title{
EFEKTIVITAS PEMBERANTASAN PUNGUTAN LIAR DALAM PELAYANAN PUBLIK DI DESA PANGSAN KECAMATAN PETANG KABUPATEN BADUNG
}

\author{
I Putu Putra Ariasa, Ida Ayu Putu Widiati, Putu Suryani \\ Fakultas Ilmu Hukum Universitas Warmadewa, Denpasar - Bali, Indonesia \\ cokputra0506@gmail.com, widiati_dayu@yahoo.com, putusuryani099@gmail.com
}

\begin{abstract}
Abstrak
Pungutan liar menjadi salah satu bentuk tindak pidana yang sudah sangat akrab terdengar di telinga masyarakat. Pada dasarnya pungutan liar dan korupsi merupakan perbuatan yang sama dimana kedua perbuatan itu menggunakan kekuasaan untuk tujuan memperkaya diri dengan cara melawan hukum. Berdasarkan latar belakang masalah tersebut, penelitian ini dilakukan dengan tujuan menggambarkan bagaimana pelaksanaan pelayanan publik pada kantor Desa Pangsan Kecamatan Petang dan bagaimana efektivitas pemberatasan pungutan liar pada pelayanan publik di kantor Desa Pangsan Kecamatan Petang. Penelitian ini menggunakan metode penelitian hukum empiris. Hasil penelitian ini menunjukkan bahwa pelaksanaan pelayanan publik pada kantor Desa Pangsan Kecamatan Petang telah memperhatikan indikator-indikator teknis sesuai dengan tata kerja prosedur. Pada Desa Pangsan standar prosedur juga memiliki fungsi membentuk sistem kerja dan aliran kerja yang teratur, sistematis dan dapat dipertanggungjawabkan. Efektivitas pemberatasan pungutan liar pada pelayanan publik di kantor Desa Pangsan Kecamatan Petang telah sangat efektif melalui upaya yang dilakukan sehingga mencegah terjadinya pungutan liar dalam pelayanan administratif.
\end{abstract}

Kata Kunci: Pelayanan Publik, Pemberantasan, Pungutan Liar

\begin{abstract}
Illegal levies are a form of crime that is very familiar to the public. Basically, illegal levy and corruption are the same acts where the two acts use power for the purpose of enriching themselves by violating the law. Based on the background of this problem, this research was conducted with the aim of describing the implementation of public services at Pangsan Village office, Petang District and the effectiveness of illegal levies eradication on public services at Pangsan Village office, Petang District. This study employed an empirical legal research method. The results of this study indicated that the implementation of public services at Pangsan Village office, Petang District has met technical indicators in accordance with work procedures. In Pangsan Village, the standard procedures also have the function of forming an orderly, systematic, and accountable work system and workflow. the effectiveness of illegal levies eradication on public services at the Pangsan Village office, Petang District has been very effective through the efforts made to prevent illegal levies in administrative services.
\end{abstract}

Keywords: Public Services, Eradication, Illegal Levies

\section{PENDAHULUAN}

Pada masa reformasi saat ini, publik sangat terbuka dalam menyampaikan kritik kepada pemerintahan, khususnya tentang pelayanan publik. Berdasarkan hal tersebut pemerintah sudah seharusnya mengatur dan menentukan langkah-langkah serta program guna peningkatan kualitas dari pelayanan publik kepada masyarakat. Banyaknya kritikan dan saran dari masyarakat dalam bentukbentuk pelayanan publik yang diberikan oleh pemerintah didasarkan atas masih saja ditemukan beberapa pos pelayanan yang jauh dari memadai baik secara fasilitas maupun sumber daya manusianya, sehingga tidak dapat memberikan pelayanan yang prima dan maksimal kepada masyarakat. Pelayanan yang berkualitas seringkali mengalami kesulitan untuk dapat dicapai karena aparat seringkali belum mengetahui dan memahami bagaimana cara memberikan pelayanaan yang baik. Hal ini disebabkan oleh masih rendahnya kemampuan professional aparat daerah (Abidin, 2012). 
Salah satu syarat dalam mewujudkan cita-cita bangsa dan bernegara adalah dengan memberikan ruang seluas-luasnya bagi aspirasi masyarakat, sehingga hal tersebut dapat memberikan timbal balik kepada pemerintah untuk meningkatkan pelayanan publiknya (Dwiyanto, 2005). Tujuan pelayanan publik adalah untuk memberikan pelayanan kepada masyarakat, bertanggungjawab, bersih, dan bebas kolusi, korupsi dan nepotisme. Jadi, diperlukan peningkatan dan penerapan sistem pertanggungjawaban yang jelas dan tepat.

Pejabat Desa atau Kepala Desa memiliki peran yang penting dalam meningkatkan program pelaksanaan pelayanan yang baik kepada masyarakat. Salah satu cara meningkatkan pelayanan publik adalah dengan sistem pengawasan yang diterapkan oleh Kepala Desa kepada program pelayanan publik. Pada dasarnya, pemimpin mengawasi tiga hal, yaitu: uang, bahan, dan tenaga kerja (Ibrahim, 2008). Langkah-langkah yang diperlukan dalam pengawasan tersebut adalah menentukan standar, ukuran hasil atas dasar standar, dan pengambilan tindakan kebaikan jika diperlukan. Dari perspektif sosiologi hukum, upaya pemberantasan pungli setidaknya harus menyentuh kepada tiga dimensi antara lain: tata kelola pemerintahan yang baik, penguatan regulasi, dan perbaikan kultur (S, 2019).

Bentuk perbuatan pungutan liar (selanjutnya disebut dengan "Pungli") merupakan pungutan yang dilakukan oleh beberapa oknum-oknum pegawai pemerintah yang tidak bertanggungjawab (Ramadhani, 2017). Pungli adalah salah satu bentuk penyalahgunaan kewenangan dari pegawai pemerintah untuk kepentingannya sendiri dan/atau kelompok dengan memanfaatkan kebutuhan masyarakat terhadap produk-produk pemerintah (Sina, 2008).

Salah satu fenomena yang terjadi yakni dalam Putusan Pengadilan Negeri Gianyar Nomor 63/Pid.Sus/2018/PN Gin. Terdakwa yang menjabat sebagai Kelian Dinas Banjar Margasengkala, Desa Bedulu, Kecamatan Blahbatuh, Kabupaten Gianyar meminta pungutan sebesar Rp 400.000,- untuk membuat KTP korban yang hilang serta untuk menyelesaikan pembayaran pengurusan KK dan KTP atas nama korban. Terdakwa juga meminta pungutan Rp 600.000,- untuk mengambil surat pindah dan pengurusan kartu keluarga. Dalam hal ini desa sebagai salah satu lembaga pemerintahan yang memberikan pelayanan birokrasi yang didasarkan AAUPB, haruslah melakukan pengawasan terhadap praktik pungutan liar yang dilakukan di lingkup pelayanan birokrasi desa, guna terciptanya keamanan dan kenyamanan masyarakat.

Berkaitan dengan latar belakang masalah yang telah diuraikan, penelitian ini dilakukan dengan tujuan menggambarkan bagaimana pelaksanaan pelayanan publik pada kantor Desa Pangsan Kecamatan Petang dan bagaimana efektivitas pemberatasan pungutan liar pada pelayanan publik di kantor Desa Pangsan Kecamatan Petang.

\section{METODE PENELITIAN}

Mengacu pada perumusan masalah, penelitian ini didesain dengan menggunakan metode penelitian empiris, yaitu dilakukan dengan cara membandingkan antara law in the book dengan law in the action, antara teori dengan praktik, sehingga dapat ditemukan kesenjangan hukum dan diketemukan pula solusi mengatasinya (Sunggono, 2007).

Penelitian ini dilakukan di kantor Desa Pangsan Kecamatan Petang. Desa Pangsan adalah salah satu desa yang merupakan linmas Ibu Kota Kecamatan Petang. Dalam Kantor Desa terdapat struktur organisasi desa yang mana setiap Bagian dalam Struktur Organisasi Desa memiliki tugas dan kewajibannya masing-masing. Tugas dan Kewajiban dari perangkat desa adalah sebagai berikut Perbekel Desa, Sekretaris desa, KAUR Pemerintahan, KAUR Pembangunan, KAUR Kesejahteraan Masyarakat, KAUR Keuangan, dan KAUR Umum.

Dalam melakukan penelitian hukum empiris, terdapat dua jenis data yang akan digunakan, yaitu data primer yang berupa data yang terdiri dari pengamatan peneliti terhadap realita yang terjadi di lapangan, sehingga berdasarkan hal tersebut peneliti dapat menganalisis fakta-fakta hukum yang terjadi dan data sekunder yang berupa data yang dihimpun oleh peneliti yang berasal dari peraturan perundang-undangan, buku-buku, jurnal-jurnal dan bahan hukum cetak lainnya (Saptomo, 2009).

Teknik pengumpulan bahan hukum yang digunakan dalam penelitian ini, yaitu: teknik studi dokumen yang dilakukan dengan mencatat terhadap surmber bahan hukum primer dan bahan hukum sekunder yang mana selanjutkan akan ditelusuri hal-hal yang relevan dengan isu hukum yang ditulis dan teknik wawancara yang dipergunakan guna mengumpulkan data berbasis wawancara dengan pihak-pihak yang relevan terhadap isu hukum yang diteliti (Soemitro, 1990). 
Data yang terkumpul melalui data primer dan data sekunder telah diklasifikasi dan diidentifikasi, dari data primer dan data sekunder diolah dengan menggunakan metode analisa kualitatif (Moleong, 2006). Setelah analisis secara kualitatif dilakukan, data kemudian disajikan secara deskriptif.

\section{HASIL DAN PEMBAHASAN}

\section{Pelaksanaan Pelayanan Publik pada Kantor Desa Pangsan Kecamatan Petang}

Berdasarkan hasil wawancara dengan Bapak I Wayan Martana, SH selaku Kepala Desa Pangsan mengenai standar pelayanan publik, beliau menjelaskan bahwa melihat peraturan dari Kepmenpan Nomor 63/KEP/M.PAN/7/2003, standar pelayanan publik sekurang-kurangnya meliputi prosedur pelayanan, waktu penyelesaian, biaya pelayanan, produk pelayanan, sarana dan prasarana, dan kompetensi petugas pelayanan. Oleh karena itu, target kepuasan masyarakat dapat tercapainya dan juga kinerja aparat desa menjadi lebih baik (Hasil wawancara pada hari Sabtu, 8 Agustus 2020 pada pukul 11.20 WITA).

Standar pelayanan yang diberikan kepada masyarakat disesuaikan dengan standar pelayanan prosedur yang telah ditentukan oleh Pemerintah Kabupaten Badung sebagaimana dalam Keputusan Kepala Dinas Kependudukan Dan Pencatatan Sipil Kabupatenbadung Nomor 32 Tahun 2019 Tentang Standar Pelayanan Publik Dinas Kependudukan Dan Pencatatan Sipil Kabupaten Badung. Standar Prosedur yang dimiliki dalam pemerintahan desa digunakan sebagai pedoman atau acuan bagi aparatur desa dalam melaksanakan tugas dan fungsi serta meningkatkan kinerja dan pelayanan kemasyarakatan. Selain itu, dalam pelaksanaanya juga memperhatikan indikator-indikator teknis sesuai dengan tata kerja prosedur. Pada Desa Pangsan standar prosedur juga memiliki fungsi membentuk sistem kerja dan aliran kerja yang teratur, sistematis dan dapat dipertanggungjawabkan. Salah satunya adalah contoh bagaimana alur dalam mengurus perihal pengesahan surat-surat.

Adapun kualitas pelayanan yang diberikan di Kantor Desa Pangsan, berdasarkan atas hasil wawancara dengan Ibu Desak Nyoman Hartati selaku masyarakat, yaitu "Kami selaku masyarakat selalu mendukung segala program yang dilakukan oleh pihak desa, yang mana selama ini saya dan keluarga beberapa kali mengurus administrasi di kantor desa dari pelayanan yang diberikan oleh pemerintah desa sudah sangat baik, tidak ada pungutan biaya sepeser pun." (Hasil wawancara pada hari Sabtu, 27 Juni 2020 pada pukul 09.45 WITA).

\section{Efektivitas Pemberatasan Pungutan Liar pada Pelayanan Publik di Kantor Desa Pangsan Kecamatan Petang}

Pemerasan dan pungutan liar adalah tindak pidana yang memiliki unsur-unsur yang sama dan saling berhubungan, antara lain untuk menguntungkan diri sendiri atau orang lain dengan melawan hukum disertai rangkaian kekerasan atau ancaman agar orang lain menyerahkan barang atau sesuatu kepadanya. Berdasarkan hasil wawancara dengan Bapak I Wayan Martana, SH selaku Kepala Desa Pangsan mengenai pungli yang mungkin pernah terjadi di Kantor Desa Pangsan, beliau menyampaikan "Untuk di Desa Pangsan selama saya menjabat Kepala Desa belum pernah yang namanya ditemukan atau adanya laporan mengenai kasus pungutan liar pada bidang pelayanan publik terutama pelayanan berkaitan dengan Kantor Desa." (Hasil wawancara pada hari Jumat, 26 Jni 2020 pada pukul 15.00 WITA).

Berdasarkan hasil wawancara dengan Bapak I Wayan Martana, SH selaku Kepala Desa Pangsan terkait upaya penanggulangan pungutan liar di kantor desa menuturkan bahwa pihaknya belum melakukan upaya pencegahan yang signifikan dikarenakan pungutan liar belum pernah ditemukan pada masa kepemimpinannya, tetapi guna mencegah terjadinya pungutan liar diberbagai sektor terutama di tubuh Pegawai Negeri Sipil dan pegawai kantor desa sebagai pelayan publik pihaknya telah melakukan penyuluhan-penyuluhan tentang pemberantasan budaya pungutan liar sebagai bentuk tindak pidana korupsi (Hasil wawancara pada hari Jumat, 26 Juni 2020 pada pukul 15.15 WITA).

Selanjutnya berdasarkan hasil wawancara dengan Bapak I Gusti Putu Suarnaya, selaku Kelian Dinas Desa Pangsan Tengan, dia menyatakan mengenai upaya yang dilakukan guna mencegah terjadinya pungutan liar dalam pelayanan administratif kepada masyarakat adalah dengan bersinergi dengan pemerintah desa dan Babinkantibmas dan Babinsa supaya di wilayahnya tidak terjadi pungutan liar yang mana bisa merugikan masyarakat. Pungutan tersebut merupakan pungutan yang 
tidak ada aturan yang jelas, maka bisa menguntungkan oknum yang tidak bertanggung jawab (Hasil wawancara pada hari Sabtu, 27 Juni 2020 pada pukul 12.30 WITA).

Dalam penanggulangannya pungutan liar di kantor desa memiliki banyak kendala. Menurut Bapak I Wayan Martana, SH selaku Kepala Desa Pangsan, salah satu kendala dalam upaya penanggulangan pungutan liar yaitu sulitnya menyadarkan dalam pelayanan disiplin atau seorang pegawai tentang mekanisme pelayanan kepada masyarakat dan selama ini tetap berupaya penyadaran dan pembinaan kepada bidang pelayanan masyarakat yang adil tanpa pungutan liar (Hasil wawancara pada hari Jumat, 26 Juni 2020 pada pukul 15.30 WITA).

\section{SIMPULAN DAN SARAN}

\section{Simpulan}

Berdasarkan hasil dan pembahasan di atas, ada beberapa simpulan yang dapat dibuat, yaitu: pertama, pelaksanaan pelayanan publik pada kantor Desa Pangsan Kecamatan Petang telah memperhatikan indikator-indikator teknis sesuai dengan tata kerja prosedur. Pelaksanaan pelayanan publik pada kantor Desa Pangsan Kecamatan Petang disesuaikan dengan standar pelayanan prosedur yang telah ditentukan oleh Pemerintah Kabupaten Badung dan sesuai dengan ketentuan peraturan perundangundangan yang berlaku, sehingga bentuk pelayanan publik seperti pengurusan KTP, kartu keluarga maupun surat keterangan lainnya dilaksanakan sesuai standar prosedur yang berlaku. Standar prosedur yang dimiliki dalam pemerintahan desa digunakan sebagai pedoman atau acuan bagi aparatur desa dalam melaksanakan tugas dan fungsi serta meningkatkan kinerja dan pelayanan kemasyarakatan. Kedua, efektivitas pemberatasan pungutan liar pada pelayanan publik di kantor Desa Pangsan Kecamatan Petang telah sangat efektif melalui upaya yang dilakukan sehingga mencegah terjadinya pungutan liar dalam pelayanan administratif. Upaya tersebut dilakukan oleh pemerintah desa dengan bersinergi Babinkantibmas dan Babinsa supaya di wilayahnya tidak terjadi pungutan liar yang mana bisa merugikan masyarakat.

\section{Saran}

Adapun saran yang dapat diberikan berdasarkan hasil dan pembahasan penelitian ini, yaitu: pertama, pihak aparatur Desa Pangsan agar tetap meningkatkan upaya-upaya pencegahan terhadap bentuk pungutan liar (pungli) pada pelayanan publik, khususnya mengenai pelayanan di Kantor Desa. Hal ini juga dapat diupayakan dengan pelatihan kepada para pegawai desa agar terbangun sikap integritas dan transparan dalam meingkatkan kualitas pelayanan kepada masyarakat. Kedua, masyarakat Desa Pangsan agar tetap mengawasi dan mengkritisi apabila diketemukannya bentuk-bentuk pungutan liar (pungli) pada pelayanan publik di Kantor Desa. Adanya pengawasan mandiri dari masyarakat dapat menekan tindakan oknum-oknum yang memanfaatkan jabatan.

\section{DAFTAR PUSTAKA}

Abidin, S. Z. (2012). Kebijakan Publik. Jakarta: Salemba Humanika.

Dwiyanto, A. (2005). Mewujudkan Good Governance melalui Pelayanan Publik. Yogyakarta: Gajah Mada University Press.

Ibrahim, A. (2008). Teori dan Konsep Pelayanan Publik serta Implementasinya. Bandung: Mandar Maju.

Moleong, L. J. (2006). Metodologi Penelitian Kualitatif. Bandung: Rosdakarya.

Ramadhani, W. (2017). Penegakan Hukum dalam Menanggulangi Pungutan Liar terhadap Pelayanan Publik. Jurnal Hukum Samudra Keadilan, 12(2), 263-276.

S, E. B. (2019). Pemberantasan Pungutan Liar pada Pelayanan Publik dari Perspektif Sosiologi Hukum. Wajah Hukum, 3(1), 10.

Saptomo, A. (2009). Pokok-Pokok Metodologi Penelitian Hukum Empiris Murni. Jakarta: Jakarta Trisakti.

Sina, L. (2008). Dampak dan Upaya Pemberantasan serta Pengawasaan Korupsi di Indonesia. Jurnal Hukum Pro Justitia, 26(21).

Soemitro, R. H. (1990). Metodologi Penelitian Hukum dan Jurumetri (4th ed.). Jakarta: Ghalia Indonesia.

Sunggono, B. (2007). Metodelogi Penelitian Hukum (7th ed.). Jakarta: PT. Raja Grafindo Persada. 